Desassossego

\title{
FICÇÕES TOPOLÓGICAS
}

\section{OU A CARTA DE ULISSES VAZ DE RIEMANN \\ (crónica- ensaio)}

Luis Lima ${ }^{1}$

O centro do mundo encontra-se simultaneamente em diversos lugares. De facto, qualquer que seja o lugar escolbido, ele pode ser o centro de um outro lugar e é inútil tentar demonstrar que é de outro modo.

Samuel Tenenbaum

\section{Sinopse}

Cartografar lugares (topos) do imaginário, trazendo esse mesmo imaginário para o real de que faz parte, é a motivação principal desta crónica ou caderno de viagem. Oriundos da mais pura ficção, estas zonas inclusivas irrompem segundo a lógica (logos) de um explorador pósgeográfico - qual Magalhães pós-humano ou demasiado humano - que bem sabe que não há ciência sem imaginação. Do real para a imaginação e volta, eis um ensaio de circumnavegação para-literária e para-científica que visa escrever, grafar, traçar uma carta.

\footnotetext{
${ }^{1}$ Pesquisador no Centro de Estudos de Comunicação e Linguagens da Universidade Nova de Lisboa.
} 


\section{Ficções Topológicas * \\ Ou A Carta de Ulisses Vaz de Riemann}

Tinha ouvido falar de um ramo da análise matemática, surgido no século XVI das cogitações de Gottfried Wilhelm von Leibniz designado analisys situs². Sabia que servira para conceber uma geometria da posição. Sabia também que esta disciplina incidira sobre os conjuntos abertos ou espaços elásticos e que se dedicava a estudar as posições singulares. Trata-se pois de localizações que não constam em qualquer mapa, carta ou plano geográfico, mas que se inscrevem em mapas, cartas ou planos topológicos. Em finais do século XIX, este ramo científico mudou de nome, e passou a ser conhecido por Topologia [do gr. tópos e do lat. topos ou topus (lugar, localidade, sítio, território) e do gr. lógos (tratado, estudo, ciência)] $]^{3}$. Sendo a literatura um campo por excelência fértil neste tipo de criação - lugares mentais, directamente saídos das junções sinápticas cerebrais e canalizados para a tinta da china, pulsada pela mão, até ganharem consistência nos planos de celulose, cartas e mapas -, rapidamente a associei à topologia, dando início ao meu geo-périplo. Um périplo em que a topologia surge como um elemento de pensamento nómade através de lugares abstractos ou imaginários, lugares vagos aonde apenas se chega por vizinhança, por percurso, por entradas e saídas específicas e totalmente individuadas pela expressão literária. São zonas de indiscernibilidade, de aproximação por vizinhança, são reinos cujas fronteiras são mais que uma linha e menos que uma superfície, e cujos territórios são mais que uma superfície e menos que um volume e cujas coordenadas configuram mais que um ponto e menos que uma linha: dimensão fractal a destas ficções topológicas; ordem física caótica a das normas

\footnotetext{
2 Para Leibniz, esta nova análise devia ocupar-se unicamente da posição e das propriedades dela provenientes, sempre que não se tenha que ter em conta as quantidades nem o seu cálculo. Eram, por isso, posições qualitativas, e é, precisamente, o que aqui nos interessa: esse plano criativo da qualidade e da imaginação ficcional.
} 


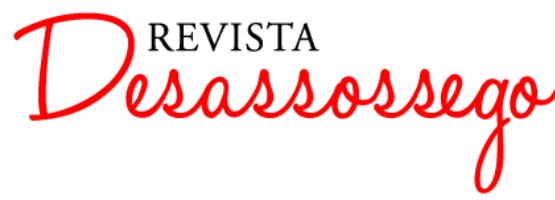

que regem estes territórios muitas vezes vagos e incircunscritos, mas nunca vazios. Aproximava-me mentalmente do meu objectivo. Iria percorrer vórtices criados na mente de Kafka, Verne, Poe, Camões ou encantar-me com o País das Maravilhas. Mas como não condenar de antemão esta investida a uma deriva estéril e eterna? Cingindo-me exclusivamente a lugares da imaginação que possam ser inscritos na superfície (ou por debaixo dela) do planeta Terra. E seguro de que viajando munido de guias, mapas e documentação vária recolhida nos escritos de poetas, romancistas e ficcionistas de todos os quadrantes, não corria riscos desde que tomasse alguns cuidados especiais - na minha mala de viagem (uma notável mala-dobradura) estaria sempre presente o imprescindível dicionário de Manguel e Guadalupi. Fiz-me assim ao caminho, com os devidos cuidados que me foram soprados por Deleuze e Guattari, a não esquecer em caso algum: as passagens fazem-se no limite e pertencem por isso ao vago, ao anexacto (e não inexacto) e serão todas, doravante, nómadas, pois a única fronteira que interessa é constantemente móvel.

La variabilité, la polyvocité des directions est un trait essentiel des espaces lisses, du type rhizome, et qui en remanie la cartographie Gilles Deleuze e Félix Guattari

\section{Américas}

Revisitava mentalmente, desde o seu início, o processo que me tinha levado a tomar a decisão desta exploração. Acabava de reler as frases escritas acima quando, iniciado no meu próprio périplo, percebi que, acabrunhado nestas cogitações, tinha acabado de ultrapassar os limites de um país, tinha deixado para trás uma ficção topológica. Reclinando-me prontamente sobre o meu bloco de apontamentos pude ler o que escrevia: "Nutopia, país sem território ou fronteiras e apenas circunscrito pelos seus habitantes que são os seus embaixadores. País que vive segundo as leis do Cosmo e foi localizado por John Lennon e Yoko, em Mind Games, no ano de 1973". Lidas estas linhas, ergui de leve a cabeça para ouvir

${ }^{3}$ A topologia que aqui se eleva a termo conceptual estende-se mesmo ao pensamento filosófico de Gilles Deleuze e Félix Guattari, ao espaço de Riemann, e às dimensões fractais de Mandelbrot, Von 


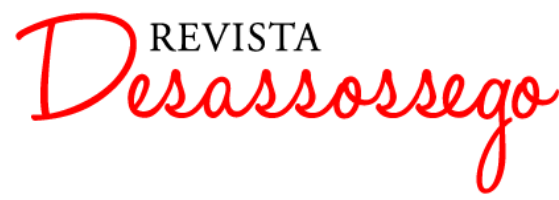

melhor a sonoridade que vinha de uma certa lonjura, sentida por instantes e logo perdida. Era uma melodia abafada que se revelou ser o hino nacional de Nutopia, entoado na embaixada de Nova Iorque, 1, White Street, 10013, USA.

Comecei a caminhar tranquilamente pelo Soho enquanto pensava falando: "urge agora efectivar a conexão, estabelecer o modo de ligação para um outro lugar no meu plano de ficção", disse, a pensar. Sabia que era por via do espaço liso que conseguiria alcançar a minha próxima meta - Califórnia. E sabia ainda que o espaço liso é o da mais pequena distância, que é um espaço de contacto, de pequenas acções de contacto, tácteis ou manuais, mais que visuais. Por isso, tacteando, retirei da algibeira do meu fato de turista as coordenadas da próxima zona a explorar. Claro que tive em conta o modo de leitura das latitudes e das longitudes. As longitudes referem-se aos movimentos e às relações de extensão enquanto as latitudes dizem respeito à velocidade e à lentidão. "O movimento é extensivo e a velocidade intensiva, delimitando os movimentos e a colocação dos corpos no espaço", murmurei, como quem recita uma proposição de Espinosa ou uma expressão de Foucault. E precisava de ambas para mapear um topos, um lugar: " $43^{\circ} 11^{\prime} 13^{\prime \prime}$ de latitude norte e $124^{\circ} 41^{\prime} 173^{\prime \prime}$ de longitude Oeste", o que corresponde à costa Oeste dos Estados Unidos da América, numa região entre as actuais C. Blanco e North Bend, Myrtle Point, estado de Oregon. Mas estas coordenadas precisas indicam um lugar perfeitamente individuado, mais concretamente uma cidade, que não existe nos Atlas. France-Ville é essa cidade-modelo que Jules Verne, em 1879, diz ter sido fundada sete anos antes pelo Dr. François Sarrasin, e situa-a, exactamente, na Califórnia. Dos meus utensílios de viagem fiz ressaltar mais alguma informação sobre esta cidade estadunidense de nome tão dedicadamente europeu: "Limpar, limpar sem parar de maneira a destruir os miasmas que emanam constantemente de uma aglomeração humana", tal é a obra principal do governo central da região de France-Ville, terra onde as crianças, desde os quatro anos de idade, praticam os exercícios necessários para o bom desenvolvimento muscular e cerebral, com vista à limpeza individual e colectiva da comunidade. E então pude perceber que tipo de modelo era este, anotando: “a água jorra por toda a parte, as ruas são pavimentadas com madeira betumada e os passeios públicos ostentam o brilho da pedra polida. São a montra dos desígnios locais de tão elevada

Koch ou Sierpinsky. 
assepsia.” Em France-Ville, também a saúde pública alimentar é regida por férrea legislação; um comerciante que venda um ovo podre, uma carne danificada, leite azedo, é acusado de envenenador público. Graças a estas precauções, são poucos os hospitais e quase exclusivamente reservados a estrangeiros e alguns excepcionais casos locais. Devido a toda esta rigidez normativa, é costume entre as gentes de France-Ville, distribuir-se a cada viajante, às portas da cidade, um prospecto limpidamente redigido, com os princípios mais importantes para se levar uma vida regular segundo os ditames da ciência. Daí retirei algumas das notas acima mencionadas.

$\mathrm{Na}$ clara orla da cidade, os meus sentidos, como que sob o efeito de psico-trópicos higiénicos, foram afectados pela percepção de que haveria outras formas na natureza - não formas visíveis mas formas integradas no processo de criação ficcional - à espera de serem descobertas. E, como qualquer líquido ou gás é uma colecção de elementos individuais, em tal número que tudo se passa como se fossem em número infinito, cada ficção topológica é uma individuação devidamente colocada e composta por uma multiplicidade de elementos. Como cada um desses elementos se move de modo independente, esse fluido individual, que é o lugar ficcional, tem infinitas possibilidades e infinitos «graus de liberdade», mas como cada uma das partículas depende muito do comportamento das suas vizinhas, este fluxo tem uma certa regularidade e os seus graus de liberdade têm, assim, de ser reduzidos. Encontramse delimitados por uma fronteira também ela fluida e elástica, que corresponde ao seu grau ficcional. Sendo esta uma limitação exclusivamente geográfica, ou pós-geográfica, não me causou constrangimento e pude prosseguir viagem. Rumo à América do Sul, em busca, enfim, à procura, bem, na senda do El Dorado. Para alcançar esse território contava com todas as informações necessárias, sorvidas nos relatos de Sir Walter Raleigh, Garcilaso de la Vega e de Voltaire. Sabia que se tratava de um reino inserido nas terras que se estendem entre a Amazónia e o Peru. E viria a saber muito mais... como a origem do seu nome, que provém de uma antiga prática entre os habitantes do reino: "uma vez ao ano, o rei é untado de óleo e totalmente recoberto de ouro em pó, tornando-se assim el dorado", anotei no meu bloco de apontamentos enquanto um dos habitantes me esclarecia. Fiquei ainda a saber que, dada a abundância de ouro nas paragens, os habitantes ignoram a cobiça e consideram os seus tesouros supérfluos: “o ouro, que não serve senão para embelezar palácios e templos, é 


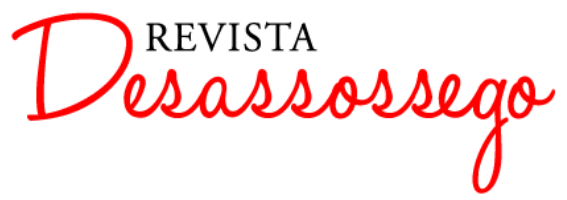

inferior aos alimentos e bebidas", disse-me outro interlocutor eldoradês. Durante toda a estadia no reino, fui amavelmente tratado, como é, aliás, habitual nestas paragens, e foi-me recomendado saborear as especialidades locais. Comi o estufado de papagaio e repeti a dose de colibris recheados. Por fim, e receando ser alvo da chacota geral, coibi-me de trazer algumas pepitas de ouro e pedras preciosas na algibeira. Ainda assim, abandonei esta terra com uma enorme sensação de riqueza.

Le voisinage est une notion à la fois topologique et quantique, qui marque l'appartenance à une même molécule, indépendamment des sujets considérés et des formes déterminées.

Gilles Deleuze e Félix Guattari

\section{Antárctida}

Mais para meridião, e para lá das Américas, encontrei o Presente. À chegada, o meu relógio parou - "até um fiabilíssimo Nomos de tecnologia alemã, da antiga RDA, sofre os efeitos do Presente", indignei-me. O fenómeno é natural e as queixas junto dos melhores relojoeiros continuam sem resposta. Mas onde estava eu, afinal? Próximo do Pólo Sul, num país cujos habitantes não possuem memória e em que cada instante é novo e renovadamente perfeito. Isto era tudo o que então sabia, e sabia-o pela pena de Edgar Allan Poe, que aqui tinha enviado Mr. Arthur Gordon Pym, alguns anos antes de mim (em 1828), para explorar... este Presente, justamente. Quem quiser vir até cá de avião deverá saber que a $3000 \mathrm{~m}$ irá sobrevoar, depois de atravessar um leve nevoeiro, uma cordilheira de montanhas repletas de crateras vulcânicas, de onde se elevam fumaças incandescentes. Do ar, uma vista de olhos é suficiente para vislumbrar o país do Presente: no sopé das montanhas, estende-se uma planície fosforescente, branca e azul, salpicada de lagos e charcos ligados entre si pela sinuosidade dos canais e das correntes. À beira da água, a areia é cor de cinza. Da interessante flora, destacam-se os ramalhetes de corais brancos e luminosos, as árvores de folhas opacas e redondas, os frutos cheios e transparentes, como o cristal. Tudo isto é acontecimento puro no Presente. Tal como é cada instante singular que vivem os indígenas que encontrei. Toda e qualquer vida está suspensa, por um fino fio essencial, a esse tempo 


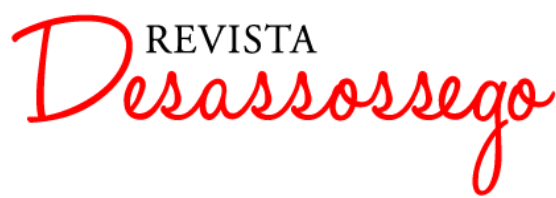

imutável mas sempre novo. Tudo é claro; não há mistério nem mentiras, nem cansaço, nem sequer dor. "Os habitantes do Presente são uns humanóides andróginos, translúcidos como jade branco, cujos dedos espalmados - à excepção do polegar - formam uma mão semelhante à barbatana de um peixe japonês", isto tinha eu lido de Poe. E confiei-o ao meu bloco de notas: "têm grandes olhos, cabelos curtos, dentes e unhas de nácar (substância mais conhecida por madrepérola), corpos elegantes e gestos graciosos”. A dada altura, estes seres até me incitaram a participar no seu renova-momento favorito: brincar na água das bacias. Declinei, é claro - pensando, "Como devem precisar de renovar os momentos, estes presentinos, já que não conseguem matar o tempo!”. Os andróginos do Presente antárctico comunicam através de uma língua musical e não são afligidos por nenhum dos vícios humanos.

Le clinamen, comme angle minimal, n'a de sens qu'entre une droite et une courbe, la courbe et sa tangente, et constitue la courbure première du mouvement de l'atome. Le clinamen, c'est le plus petit angle par lequel l'atome s'écarte de la droite. C'est un passage à la limite, une exhaustion, un modéle «exhaustif» paradoxal.

Gilles Deleuze e Félix Guattari

\section{Atlântico}

Posto isto, não foi sem uma certa ansiedade que deixei o Presente. A situação era já de si complicada e, às ficções topológicas, acresciam-se agora novas dificuldades, directamente decorrentes da imanência das experiências, percepções e afecções desta destinerrância. Seguiria para o futuro ou para o passado? Melhor, para um futuro ou um passado? Sem resposta, prossegui no presente contínuo. Indo. Norteando, em pleno Oceano Atlântico. Querendo chegar a um lugar ao qual nunca se pode regressar. Uma espécie de vai mas não voltes. Pelo menos, assim consta que um certo Robinson o entendeu. Esse lugar, acabei por encontrá-lo a vinte léguas da costa sul-americana, na latitude da foz do Rio Orinoco. Há quem lhe chame Esperança ou Ilha do Desespero, mas é mais conhecido por Ilha de Robinson Crusoe. Para poder mais tarde regressar à ilha, contrariando uma das suas principais propriedades topológicas, percebi de imediato que urgia tirar notas, muitas e rigorosas. Até porque desejava completar os relatos de Daniel Defoe e Michel Tournier, que trazia na minha mala de infinitas dobraduras. Anotei: "o interior montanhoso da ilha está 


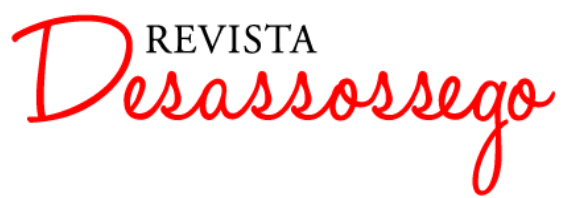

cortado por um vale fértil. As praias e baías não faltam. A Foz de um rio, a nordeste, forma um porto bem protegido.” Ao passear pelo insular território, encontrei os vestígios dos três acampamentos construídos por esse Robinson Crusoe, nativo de York, que aqui naufragou, permitindo, graças às confissões do seu diário, que a ilha viesse a ser conhecida. Mais adiante, ao sul, cheguei à Baía de Sexta-Feira, onde Crusoe avistou, pela primeira vez, a marca de um pé humano, e onde ossaturas - restos de um festim antropófago - são ainda reconhecíveis. Parei e copiei as notas que o pobre náufrago inscreveu num poste que lhe servia de calendário: "Desembarquei aqui a 30 de Setembro de 1659". Era tempo de ir embora.

Le plan de consistance est un plan de variation continue, chaque machine abstraite peut être considérée comme un 〈plateau» de variation qui met en continuité des variables de contenu et d'expression.

Gilles Deleuze e Félix Guattari

\section{Europa}

Por momentos, regressado ao que julgava ser a minha escrita, que de tão estática me ia transportando através do movimento de todos os corpos celestes que em redor se movimentavam, eis que estava a caminho de um outro continente, na translação da minha condição de explorador pós-turístico e pós-científico, de Ocidente para Oriente, agora. Europa, Reino Unido, Inglaterra. Segundo os escritos de Lewis Carroll, não devei estar longe da entrada da toca do coelho branco de fatiota. Sabia que se encontra aqui em Oxford, à beira do Tamisa, algures entre Folly Bridge e Godstow (nomes que, quando traduzidos para português, resultam nuns sugestivos Ponte da Loucura e Guardadeus). Sabia também que esse corredor subterrâneo conduz directamente ao País das Maravilhas. Ainda segundo as informações de Caroll, esse tal país foi visitado, pela primeira e única vez, por volta de 1865, por uma menina chamada Alice. E eis que..., de repente, caio lentamente. Enquanto se dava a terrivelmente longa e demorada queda, saquei de dentro de um dos bolsos do meu fato de turista o lápis e o bloco de apontamentos, preparando-me para o que aí vinha. Através de 


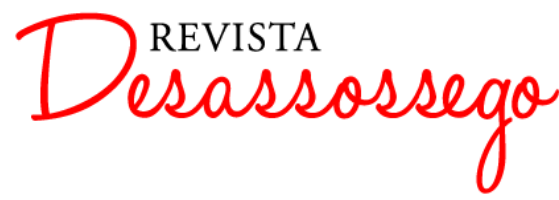

artigos domésticos, a minha queda terminou em cima de um monte de arbustos e folhas secas. Recompondo-me rapidamente, segui por um corredor que conduz a um quarto baixo e iluminado por uma fileira de lâmpadas suspensas do tecto. De todas as portas que dão acesso a essa peça, escolhi a mais pequena. "Mas primeiro é preciso abri-la", observei. Para isso usei a minúscula chave de ouro que teima em luzir sobre uma mesa de vidro. Como tudo é pequeno, e como sou maior que um rato, é preciso bebericar um tónico ou comer alguns biscoitos dispostos sobre a mesa. É que, no País das Maravilhas, a comida e a bebida fazem aumentar ou diminuir de tamanho, pelo que é necessário usá-las, mas com moderação. Dos meus apontamentos, releio agora o que anotei: “O delicioso guisado do Coelho branco deve ser provado, a cozinha da Duquesa e o salão de chá ao ar livre do Chapeleiro Louco, que está sempre aberto, merecem ser visitados." Isto para as especificidades. Quanto aos poderes do estado notei que "No País das Maravilhas quem governa é o rei e a rainha de Copas, estando o poder concentrado nas mãos da rainha" e que “a morte por decapitação é uma pena comum, mas raramente aplicada”. No que toca à flora do reino, há que dizer que é bastante pobre, e acrescentar: "destaca-se uma espécie de rosa branca, por vezes pintada de vermelho, que cresce nas proximidades do campo de críquete da rainha”. Em compensação, a fauna é notável: “os animais falam inglês, na sua maioria, à excepção dos ratos, que também dominam o francês." Espécies numerosas e variadas coabitam: “cães, porcos da Índia, porcos espinho, caranguejos, arenques, coelhos trajando colete, lagartos, rãs, lebres de Marte, tartarugas "fantasia" (uma raça bastarda, originada pelo cruzamento de um boi e de uma tartaruga)", e outros, que não tive tempo de conhecer. Depois, há o encantador Gato do Cheshire, identificável pelas suas observações perversamente subtis, e dificilmente localizável, pois tem o dom de se tornar invisível, deixando apenas o seu sorriso a flutuar no ar. Topológico e extremamente ficcional, este lugar é de uma natureza tal que apenas por assim ser é possível que seja estranho e desconhecido. Por ficção entendia agora, no actual contexto da minha destinerrância, a condição última da eterna exploração e investigação, que surge não em oposição ao conhecimento científico experimental mas sim aquém e além deste. "Aquém e além mar...", pensei, escrevendo. E estas palavras soaram-me familiares. Como que despertado de um certo torpor, sentia-me subitamente em casa. Permanecendo no continente europeu, rumava, 


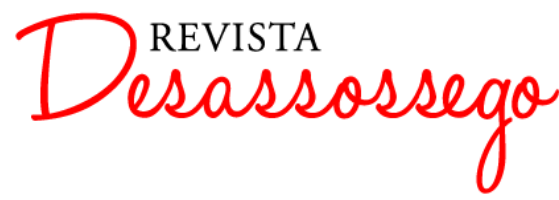

pois, para a grande foz do rio Tejo, em Lisboa, Portugal. "Estou algures no Mar da Palha, ou até mesmo em frente ao porto da capital. Sinto uma certa ondulação, por debaixo dos pés que estão, no entanto, assentes em terra firme", escrevi no meu bloco. "Estarei já na ilha flutuante?" Estava, estive e estou. Constavam dos meus arquivos portáteis dados de uma obra de 1724, da autoria de Thomas Artus, intitulada "Descrição da Ilha dos Hermafroditas novamente descoberta, contendo os hábitos e os costumes dos habitantes dessa ilha...". Por isso lá estava - não longe de minha casa, aliás. A primeira sensação foi de estranheza, "daqui não se vêem as pontes sobre o Tejo e os habitantes são... antes, não são homens e mulheres mas sim homens-mulher, quer dizer, hermafroditas...”, observando, registei. É, aliás, desta característica sexual que deriva o nome da ilha que, por sua vez, deriva por sobre as águas do Tejo. Na Ilha dos Hermafroditas, tentar um diálogo com um habitante não é fácil, pois a língua falada é um erudito latim, que não domino - se bem que a origem da República hermafrodita seja atribuída ao feito de um deus do Sol assírio-fenício, o Heliogabalo. Desistindo das conversas, fui ao encontro das muitas singularidades insulares, como a cultura clássica eminentemente dominante. Ao calcorrear a ilha, tive então a nítida sensação de estar num enorme teatro ao ar livre - isto, devido aos ritos religiosos que obrigam ao longo de todo o ano os habitantes a encenar por toda a parte peças inspiradas na antiguidade, como O Rapto das Sabinas, Artaxerxes e a sua Filha, Acteon Devorado pelos seus Cães, As Ocupações Lascivas de Sardanapale, entre outras. Anotei: "No campo arquitectónico, as construções distinguem-se por elegantes traços helénicos, como colunatas ao longo das ruas. No centro da ilha, eleva-se a estátua de um Heliogabalo: a seus pés, as tábuas da lei gravadas na pedra". Aqui, a beleza é a rainha das leis e a volúpia igual à santidade. Apesar de ter permanecido por pouco tempo, foi o bastante para perceber que todos os meses se celebra o mês de Maio. Foi, assim, em Maio que cheguei à Ilha dos Hermafroditas e "é em Maio que me vou embora”, escrevi no meu bloco de apontamentos.

As coordenadas que trazia na minha bagagem [já descrevi a minha velha mala de couro encardida pelo espaço, cujo interior é feito de dobras sobre dobras, até ao infinito, de um modo tal que até a superfície exterior aí está contida? Como nela está tudo aquilo que fora dela está, revela-se muito útil para qualquer viajante topológico; à semelhança, aliás, do meu bloco de apontamentos, cujas notas são o registo da sua própria escrita] eram, mais uma 


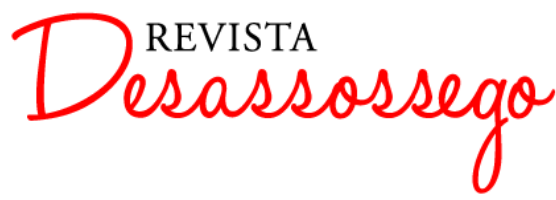

vez, anexactas. Eram precisas mas não exactas e não eram inexactas, precisamente, pela sua indeterminação. Indicavam, num texto datado de 1926, um castelo na Boémia. Um estranho Castelo, cuja principal estranheza lhe advinha, precisamente, desse nome: O Castelo. É de Kafka a sua primeira e maior descrição. E foi o mesmo Franz que o baptizou, singularmente, Das Schloß. "A fortaleza sem nome é um amplo conglomerado de edifícios com dois andares alternando com casas baixas, apertadas umas contra as outras", apontei. Ao chegar, julguei tratar-se de um simples vilarejo e não de uma fortificação. Mas depressa percebi que o castelo tem apenas uma torre redonda, em parte recoberta por hera e perfurada por algumas janelas. As ameias da torre são incertas, irregulares, e parece prenderem-se ao céu como o desenho tremente de uma criança negligente ou tímida. A atmosfera que se vive na aldeia, situada nas margens de um ribeiro e totalmente dominada pelo castelo, é opressiva. Aqui, ninguém tem o direito de viver ou pernoitar sem a autorização do conde, o senhor do lugar. Travei, entretanto, contacto com alguns habitantes do castelo, muito desconfiados, e registei "todos possuem a mesma estranha característica física: um crânio deformado pelas pancadas e um rosto que é uma verdadeira máscara de dor." Como o Inverno é prolongado nesta região e a aldeia se encontra normalmente coberta de neve resolvi abandonar $\mathrm{O}$ Castelo, frisando: "Não é sem uma certa sensação de alívio que abandono este lugar".

Le plan consiste abstraitement, mais réellement, dans les rapports de vitesse et de lenteur entre éléments non formés, et dans les compositions d'affects intensifs correspondants («longitude» et «latitude»du plan).

\section{Gilles Deleuze e Félix Guattari}

\section{África e Ásia}

Os meus passos deixavam nas minhas costas um rasto na neve e, à medida que rememorava as feições de dois rostos, dos mais marcantes do Castelo, comecei a sentir uma forte humidade atravessar o meu fato de turista. Sentei-me para actualizar as minhas notas, quando percebi que estava exactamente em cima de um enorme formigueiro. Depois de me livrar de todos os insectos que caminhavam decididamente sobre mim, subi a uma árvore para perscrutar o horizonte. O calor era agora tórrido e a humidade ainda maior. Da minha mala-dobradura retirei um texto de Edgar Rice Burroughs que descrevia um reino, algures 


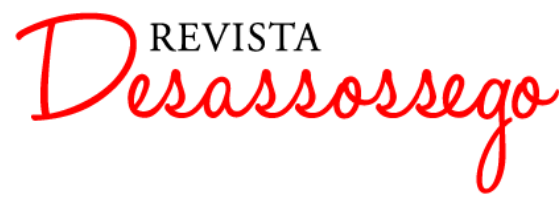

em África, situado nas cúpulas das árvores. Segundo Burroughs foi a(qu)í que cresceu Lord Greystoke, de cognome Tarzan da Selva, criado pela tribo dos grandes macacos Nangani depois de estes terem massacrado o seu pai. "Estou no Reino dos Macacos", suspirei, escrevi. E li mais um pouco daquilo que estava prestes a redigir no meu bloco de apontamentos: "Se vivem habitualmente no coração da selva tropical, os macacos viajam muito e vão, por vezes, passar meses inteiros numa localidade longínqua. Adormecem, quando chega a noite, ao abrigo das folhas da planta com orelhas de elefante." Não me atrevi a contactar de perto com os macacos, numa mistura de medo e de purismo de observador. Mas vi que obedecem a certas leis estritas. Anotei alguns exemplos: "se uma fêmea é raptada, pode escolher entre o seu raptor e o seu marido. Se escolher o primeiro, deverá dar ao segundo uma das suas filhas em troca. Se um marido bate na sua mulher, esse culpado é castigado pelo chicote, manejado por um dos mais velhos membros da tribo". Das leis é tudo o que sei, quanto aos festejos e celebrações, uma é de importante envergadura. É a dança Dum-Dum, que decorre num anfiteatro natural, no centro do qual se encontra um tambor, tendido especialmente para esta festa delirante. Consta, no dicionário de Manguel e Guadalupi, que folheio rapidamente, que esta prática está na origem de todas as celebrações da Igreja e do Estado. Mas são dados que permanecem por confirmar.

Daqui até ao Reino do Preste João, a viagem não foi nada simples. Foi preciso encontrar na minha mala a carta escrita pelo próprio Preste ao Imperador Manuel (de Bizâncio) e a sua clonada versão endereçada ao germânico Imperador Frederico, o Barba Ruiva. O texto da carta entrecruzou-se, porém, com diversos outros. Como que através de hiperligações. Começava a ler uma frase num texto e acabava de lê-la num outro. Segundo os escritos de Umberto Eco, a carta original foi escrita por Baudolino que, depois de ter estado às portas do reino, em Pnapetzim (uma cidade governada pelos súbditos eunucos e onde pululam ciápodes de uma só perna, gigantes, sátiros-que-nunca-se-vêem, panóceos, lindas hipáceas meio mulher, meio cabra, entre muitos outros seres surpreendentes) regressou a Bizâncio onde se tornou estilista. Depois, partiu para viver os anos que lhe restavam num retorno ao Reino. Estes são os dados de Umberto Eco que rapidamente se inscrevem, na minha encardida mala-dobra, nas análises de Manuel João Ramos. "Estou ainda na Etiópia?”, pergunto-me, “ou já na Índia?”. Constatei que o bestiário não é característico de 
nenhuma delas, mas antes de mais do que elas. Cruzei-me com enormes elefantes e leões, penetrei em sumptuosos e engenhosos palácios e assisti até a uma pregação pública de São Tomé. Terei ido até ao Ceilão? "Seja onde esteja, fui", poetizei. Palmilhei, pois, essa terra mas, infelizmente, perdi o bloco de apontamentos que aí redigi, não podendo agora, senão de memória, relatar tudo aquilo que me foi dado a ver... Exceptuando que, de Ocidente para Oriente, dei por mim na bíblica Gangarrida. Depois? Shangri-La estalou-me no ermo dos ouvidos. Julgo que o estalo se deveu à forte densidade atmosférica que se faz sentir nas altas montanhas dos Himalais. Sim, esse enclave tibetano dos lamas, hoje sob domínio chinês, colocado algures junto do monte Karakal e que encerra preciosidades do mundo ocidental, abria-se diante dos meus olhos. Shangri-La, onde se vive mais de 250 anos em plena juventude, foi fundada, em 1734, pelo padre Perrault - um luxemburguês nascido em 1681, autor da tradução tibetana dos Ensaios, de Montaigne - e redescoberta por Edgar Allan Poe, foi explorada por James Hilton, por Adolfo Bioy Casares, por Maurice Roche e por António de Andrade. Das conversas entre eles, dos relatos que me foram confiados, das pesquisas na minha bagagem, chegaram-me os indícios que rapidamente confirmei em terra firme, e fria que as alturas tibetanas não perdoam. Estava agora a viver momentos de extrema descoberta no apertado desfiladeiro que abriga a lamaica cidade até ao vale em que se recolhe. Nas proximidades, o famoso monte sagrado, o Karakal (ou Montanha Azul) é omnipresente, do alto de seus 8.500 metros. "Os lamas cuidam de uma população composta, em maioria, por tibetanos e chineses que apenas conhecem castigos legais por actos de extrema gravidade. Não havendo polícia nem militares, o castigo supremo, banir o malfeitor, é aplicado pelos próprios lamas convencidos que, para governar perfeitamente é preciso evitar governar em excesso", anotei. O clima do vale de Shangri-La, abrigado do vento, é contrastado e, apesar da altitude, não senti nenhum desconforto. Antes pelo contrário, os costumes locais e este clima singular parecem estar na origem de um estranho fenómeno de prolongação anormal da duração de vida, acompanhada de um envelhecimento muito tardio. Mas assim que se abandona o vale de Shangri-La, o tempo parece acelerar e uma senilidade avançada apoderase do corpo e do espírito do aventureiro. Por isso, e antes que qualquer densidade atmosférica ou flutuação meteorológico-cultural me afectasse, resolvi traçar azimutes numa direcção distante e pacífica. Das mais elevadas montanhas do globo, da mais altaneira de 


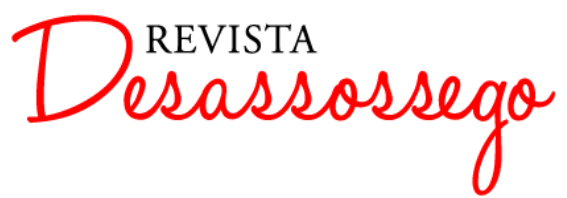

todas as cordilheiras, quase a tocar na medieval cúpula celeste, a minha viagem só poderia, agora, fazer-se num sentido - rumo ao Pacífico.

Ce qui s'inscrit sur le plan de consistance, ce sont: les haeccéités, événements, transformations incorporelles apprébendées pour elles-mêmes: les essences nomades ou vagues (...); les continuums d'intensité (...); les devenirs (...); les espaces lisses

\section{Gilles Deleuze e Félix Guattari}

\section{Austrália e Índico}

Depois de cruzar o enorme oceano dirigi-me para o centro ou o norte da Austrália. Sabia ser esta a única maneira de alcançar Erewhon. Essa terra cujo nome em português se escreve Serunhen. A primeira confirmação que pude fazer ao chegar a Erewhon é que os habitantes nunca acreditam naquilo de que têm a certeza, aliás, sabia-o devido aos escritos de Samuel Butler - documentos que, avisadamente, trazia comigo. A minha incursão neste território australiano é pouco descritiva e pouco concisa pela proibição que recai sobre os viajantes que aqui vêm de desvendar a sua localização exacta. É que os serunhenenses são um povo desconfiado. A sua fisionomia é do tipo mediterrâneo, com um belo porte. São dotados de um nariz grego e a sua aparência lembra, ao mesmo tempo, as raças egípcia, italiana e grega. As mulheres são belas, cortesãs e doces. Os visitantes loiros ou de olhos azuis são muito apreciados (pior para mim) e beneficiam de um tratamento de especiais favores. No que toca a normas sociais, o nascimento é um tema delicado e doloroso que é preferível não abordar, pois está ligado ao sofrimento. Arrependi-me assim que esbocei uma conversa sobre o assunto. Mas já esqueci por que razão. Os serunhenenses crêem na préexistência e na vontade de vir ao mundo antes de a isso se ser convidado. Assim, quando do nascimento, fazem assinar aos bebés um certificado que atesta que foi de sua livre e plena vontade que vieram ao mundo. A educação é tomada em conta e efectuada pelos colégios de Desrazão, cuja sede se encontra a dois ou três dias de Metrópolis, a capital do reino. Fui até lá para assistir a uma aula do curso de hipotética. Percebi claramente o que anotei: "por estas 


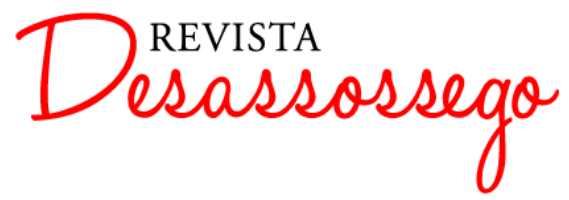

bandas, parece totalmente inútil ensinar aos jovens a natureza das coisas que os rodeiam, quando se pode prepará-los para o absurdo e o impossível". Não sei se foi aí que me fizeram uma qualquer lavagem ao cérebro, mas não posso, agora, avançar com mais pormenores sobre Serunhen, até porque a lei local o proíbe firmemente.

"Como a Austrália é banhada por dois oceanos e como aqui cheguei pelo Pacífico vou seguir caminho pelo Índico", li, escrevendo. Eis que, rumo a Madagáscar, me encontro a bordo de uma nau com estandarte ao vento e velas brancas e cheias - o navio vinha da Taprobana (um dos antigos nomes do Sri Lanka) e seguia para o Cabo da Boa Esperança enfim, ia de Oriente para Ocidente, ou seja, do Oceano Índico para o Atlântico. Foi nesse mar das Índias que surgiu a Ilha dos Amores, emergida por Vénus, por ela própria aparelhada de dons de flora e de luxúria adornada. Surgiu qual Diana perante um Actéonexplorador, amparada por formosas ninfas e ninfetas, com seios como limões. "Trata-se de um paraíso terrestre para marinheiros corajosos e sedentos, e cansados e ofegantes", anotei sem notar. Ilha de satisfação erótica e sexual. Terra do "amor indino" - Luís de Camões escreveu nas folhas que trago na minha mala-dobra mais coisas que eu próprio viria a testemunhar, sempre ao longe, pois que o explorador não pode ser participante, correndo o risco de nunca poder regressar e contar. "São cristalinos e singulares os passos das ninfas, com mil deleites não vulgares, sempre dispostas a quem desejar quanto delas os olhos cobiçarem". Estas e outras linhas copiei, mas entre todas, apressei-me a decoranotar uma: "o desejo queima e não consome". A Ilha namorada é fresca e bela; chega-se a terra firme por uma suave enseada, curva e quieta, cuja branca areia é adornada por conchas ruivas. Qualquer nauta que aqui se dirija (note-se que os lusitanos têm justo direito a um tratamento especial bem como a eternos favores) será recebido pela própria deusa do amor, Vénus. Um tal de Vasco da Gama, também conhecido por "claro Gama”, teve antes esse privilégio de estar “co’a bela Deusa”, li na minha cópia. É que “estes e outros Barões fazendo-se na terra bravos, virão lograr os gostos desta Ilha, e acharão estas Ninfas que glórias e honras são de árduas empresas", pude anotar no meu bloco de apontamentos, copiando anexactamente os versos do tal Camões. Depois de satisfazer e exaltar as necessidades do corpo, com nobre mantimento, há que seguir caminho para o interior da ilha, através do árduo mato, rumo ao erguido cume. E foi esse caminho que tomei quando percebi que era chegado o final da 


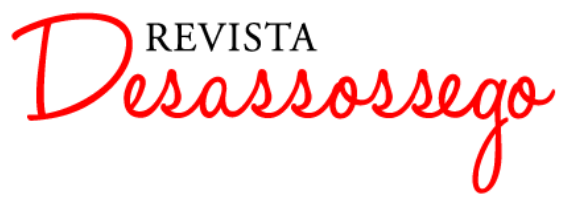

minha destinerrância. Pois que é aqui que tudo se esclarece, que a topologia desta ficção encontra a revelação. Vivi-a como segue: "no erguido cume da Ilha dos Amores, num lugar em que o chão é um campo esmaltado de esmeraldas e rubis, um globo vem pelos ares, penetrado por um lume claríssimo, de modo que o seu centro é evidente e a sua superfície clara. Transcendência imanente. Superfície profunda, espessura imediata. Possui diversas orbes, diversos lugares, muitas órbitas e fronteiras, muitos paralelos e meridianos e um só centro, o do lugar em que se está, o da colocação num determinado momento, que em toda a parte começa e acaba." E não é senão que a Vénus me deu, no cume erguido da Ilha dos Amores, uma réplica igualzinha à que dera ao "claro Gama", tal como acabo de a descrever: "uma cópia, retrato do mundo, um globo-planisfério, uma topografia clonada do mundo mais-que-real, miniatura, em pequeno volume, para que os olhos o possam ver por inteiro, para que se saiba para onde ir e se conheça aquilo que se deseja." Esta "grande máquina do Mundo”, como a escreveu Camões, etérea e elemental, permitiu-me regressar ao meu ponto de partida, à minha mecanosfera, ao meu planómetro, à máquina do universo de Vaz e Vasco. Mas são tantos, afinal, os acontecimentos literários que precisam de um lugar para existir. Um eis, algo que surge. Esse ponto singular, o lugar de toque, de contacto, de choque, acontece quando a assimptota toca na hipérbole - que "é quando a alma toca Deus", escreveu um dia Victor Hugo. É, pois, de coordenadas virtuais que se compõem as ficções topológicas. Trata-se da actualização dessas relações virtuais inéditas, mas bem reais, e aptas a devolver à vida da terra a sua ligeireza, nem que seja à tona da superfície desta carta...

* Para os relatos sobre os lugares imaginários constitui fonte fundamental o dicionário de Manguel, Alberto e Guadalupi, Gianni (1998): Dictionnaire des Lieux Imaginaires, ed. Actes Sud (orig. 1980), Paris.

Para o nomadismo e o devir topológico no espaço liso desta viagem ver, em especial, Deleuze, Gilles e Guattari Félix (1997): Capitalisme et Schizophrénie 2 - Mille Plateaux, ed. Les Éditions de Minuit (orig. 1980), Paris. 